\title{
Stress-corrosion resistance of the EN AW-AIZn5Mg1,5CuZr alloy in different heat treatment states
}

\author{
Lesław Kyzioł, Assoc. Prof., \\ Gdynia Maritime University
}

\begin{abstract}
The effect of heat treatment of the plastically worked 7000 series Al-Zn-Mg aluminium alloy system on its stress-corrosion resistance is examined. For the same chemical constitution, the effect of heat treatment on mechanical and corrosion properties of Al- $\mathrm{Zn}-\mathrm{Mg}$ alloys systems is remarkable. It was proved that a parameter having significant effect on corrosion properties of the alloy is the rate of alloy cooling after heat treatment. This conclusion is confirmed by observation of structural forms which fully reflect mechanical and corrosion properties of the alloy.
\end{abstract}

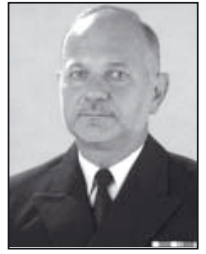

Key words: heat treatment; stress corrosion; alloy structures; corrosion resistance

\section{INTRODUCTION}

Due to their favourable mechanical properties, plastically worked 7000 series aluminium alloys have recently become an object of intensive examination, especially abroad. In Poland, the 7000 series alloy was used, among other applications, for building the superstructure of the 620 project vessel. Generally, the vessel's hull, (including the superstructure), is subject to heavy dynamic loads in unfavourable sea environment, which lead to high material effort. One of unfavourable properties of the plastically worked 7000-series aluminium alloys is their susceptibility to corrosion, especially layer corrosion in sea water environment. A rigorous parameter which determines usability of a given material for constructions which are subject to loading in sea environment is its stress-corrosion resistance. The article aims at determining the stress-corrosion resistance of the EN AW-AlZn5Mg1,5CuZr alloy in the aspect of microstructural changes resulting from the applied heat treatment.

\section{THE ESSENCE OF STRESS CORROSION OF 7000 SERIES ALUMINIUM ALLOYS}

Material stress corrosion is the synergic action of the corrosion environment and mechanical stress. It manifests itself by the appearance of cracks in the metal or alloy caused by the corrosion environment and static tensile stress. The cracks resulting from the stress corrosion are situated perpendicular to the direction of tensile stress action and can have the intercrystalline, intracrystalline, or mixed form. Observations of stress cracks have revealed that a period of incubation frequently takes place before the appearance of a detectable crack. The intensity of microcracks forming in this period can be evaluated by examining changes of mechanical properties caused by structural changes of the alloy over different timeintervals of the stress-corrosion test.

The plastically worked Al-Zn-Mg alloy systems which are to be used in marine constructions should reveal sufficiently high mechanical properties along with high resistance to cracking in the conditions of simultaneous action of mechanical stresses and corrosion environment.

Publications [1-6, 13] present the effect of selected media on the resistance of $\mathrm{Al}-\mathrm{Zn}-\mathrm{Mg}$ alloys to stress corrosion.

The present article mainly focuses on determining the effect of heat treatment on the resistance of the examined aluminium alloy to stress corrosion. The effect of heat treatment parameters on mechanical properties of this alloy was discussed in this article.

The results of the investigations have shown that in the $\mathrm{Al}-\mathrm{Zn}-\mathrm{Mg}$ alloy systems with total contents of $\mathrm{Zn}+\mathrm{Mg}>5 \%$ better stress-corrosion resistance is obtained, along with good mechanical properties, when a special heat treatment is applied which includes cooling with a "stop". This procedure preserves both good mechanical properties and high stress-corrosion resistance [7].

The type of aging after heat treatment remarkably affects the resistance of $\mathrm{Al}-\mathrm{Zn}-\mathrm{Mg}$ alloy systems to stress corrosion. Low aging temperatures $\left(<100{ }^{\circ} \mathrm{C}\right)$, in combination with longer times of aging, worsen the stress-corrosion resistance $[2,3,6]$, while two-stage aging in temperatures close to the critical temperature of GP zone solubility, especially at, $t_{s}>t_{k}$ increases the resistance to stress-corrosion cracking of the majority of alloys [2]. 
Heat treatment introduces changes in the structure of the metal. The stress-corrosion cracking is affected by the following factors:

- the PFZ width along the wide-angle grain boundaries;

- the structure of dislocations and vacancies caused by cooling after heat treatment;

- the structure of precipitates inside the matrix;

- the size and concentration of precipitates on grain boundaries [3].

Another parameter which affects stress-corrosion cracking is the presence of time-dependent tensile stresses. In aluminium alloys the increased tensile stresses almost always lead to the reduction of material durability $[8,9]$. The relation between the crack appearance time and the stress $\sigma$ which is proposed for the majority of materials has the form [10]

$$
\sigma=-\mathrm{k} \cdot \log \mathrm{t}+\mathrm{c}
$$

where:

$\mathrm{k}, \mathrm{c}-$ experimental constants.

In publication [10] the following relation is given:

$$
\sigma=\mathrm{t}^{-\mathrm{n}}
$$

where:

$\mathrm{n}-$ experimental constant.

Taking into account the effect of the examination temperature $(\mathrm{T})$ leads to the relation [11]:

$$
\frac{1}{\mathrm{t}}=\mathrm{K}_{1} \cdot \mathrm{e}^{-\frac{\mathrm{Q}_{\mathrm{a}}}{\mathrm{R}_{\mathrm{s}} \mathrm{T}}} \cdot \mathrm{e}^{\mathrm{c} \sigma}
$$

where:

$\mathrm{K}_{1}, \mathrm{c}-$ experimental constants,

$\mathrm{R}_{\mathrm{s}} \quad$ - gas constant,

$\mathrm{Q}_{\mathrm{a}} \quad-$ energy of activation $(9 \div 20 \mathrm{kcal} / \mathrm{mol})$.
Publication [12] proposes the following empirical relation

$$
\sigma=\mathrm{k} \cdot \mathrm{t}^{-\mathrm{a}}
$$

where:

$\mathrm{k}$, a - empirical constants.

\section{MATERIAL USED FOR TESTS. CHARACTERISTICS OF HEAT TREATMENT PARAMETERS APPLIED TO EN AW-ALZN5MG1,5CUZR ALLOY}

The stress-corrosion resistance of $\mathrm{Al}-\mathrm{Zn}-\mathrm{Mg}$ alloy systems was examined using $10 \mathrm{~mm}$ thick sheets of EN AWAlZn5Mg1,5CuZr alloy. At delivery conditions, the above alloy was artificially precipitation hardened (supersaturated at the temperature of $480{ }^{\circ} \mathrm{C} / 30 \mathrm{~min}$., cooled in water of temperature of $20^{\circ} \mathrm{C}$, naturally aged during 48 hours, and finally artificially aged in two stages: $90{ }^{\circ} \mathrm{C} / 8 \mathrm{~h}+135^{\circ} \mathrm{C} / 28 \mathrm{~h}$ ). In order to determine the effect of alloy heat treatment on stress corrosion the alloy was exposed to various heat treatments. The chemical constitution of the alloy and parameters of the applied heat treatments are given in Table 1 .

The materials after heat treatment were used for cutting samples from aluminium sheets in the direction perpendicular to the direction of rolling. Mechanical properties were examined on the universal testing machine MTS 810.12, for sample loads ranging up to $100 \mathrm{kN}$ and the traversing speed equal to $2 \mathrm{~mm} / \mathrm{min}$, according to the PN-ISO 377-1:1994 standard.

The stress corrosion at constant load $(\mathrm{F}=$ const $)$ was tested in a rig consisting of 12 independent sections which provided opportunities for simultaneous tests of 12 samples.

\begin{tabular}{|c|c|c|c|c|c|c|c|c|c|c|c|c|}
\hline \multirow[b]{2}{*}{ State } & \multirow[b]{2}{*}{ Heat treatment parameters } & \multicolumn{10}{|c|}{ Chemical constitution [\%] } & \multirow{2}{*}{ 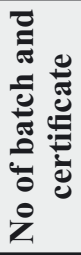 } \\
\hline & & Zn & Mg & $\mathrm{Cr}$ & $\mathbf{Z r}$ & Mn & Mg & $\mathrm{Fe}$ & $\mathbf{C u}$ & $\mathbf{T i}$ & 党 & \\
\hline T61 & $\begin{array}{c}\text { supersaturating at temp. } \\
450{ }^{\circ} \mathrm{C} / 1,5 \mathrm{~h} \text {, cooling in water at } \\
\text { temp. } 20^{\circ} \mathrm{C} \text {, natural aging in } 6 \text { days, } \\
\text { artificial aging } \\
95^{\circ} \mathrm{C} / 15 \mathrm{~h}+150^{\circ} \mathrm{C} / 10 \mathrm{~h} \\
\text { (artificial precipitation hardening) }\end{array}$ & \multirow{4}{*}{5.3} & \multirow{4}{*}{2.13} & \multirow{4}{*}{0.17} & \multirow{4}{*}{0.19} & \multirow{4}{*}{0.04} & \multirow{4}{*}{0.27} & \multirow{4}{*}{0.15} & \multirow{4}{*}{0.046} & \multirow{4}{*}{0.006} & \multirow{4}{*}{ 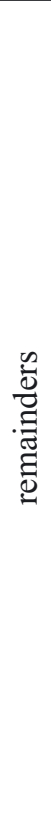 } & \multirow{4}{*}{ 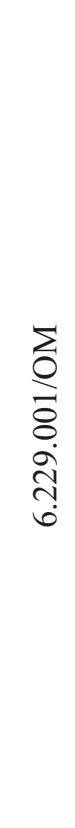 } \\
\hline T62 & $\begin{array}{c}\text { supersaturating at temp. } \\
450{ }^{\circ} \mathrm{C} / 1,5 \mathrm{~h} \text {, cooling in water at } \\
\text { temp. } 80^{\circ} \mathrm{C} \text {, natural aging in } 6 \text { days, } \\
\text { artificial aging } \\
95^{\circ} \mathrm{C} / 15 \mathrm{~h}+150{ }^{\circ} \mathrm{C} / 10 \mathrm{~h} \\
\text { (artificial precipitation hardening) }\end{array}$ & & & & & & & & & & & \\
\hline T63 & $\begin{array}{l}\text { supersaturating at temp. } \\
450{ }^{\circ} \mathrm{C} / 1,5 \mathrm{~h} \text {, cooling in air, natural } \\
\text { aging in } 6 \text { days artificial aging } \\
95^{\circ} \mathrm{C} / 15 \mathrm{~h}+150^{\circ} \mathrm{C} / 10 \mathrm{~h} \text { (artificial } \\
\text { precipitation hardening) }\end{array}$ & & & & & & & & & & & \\
\hline T4 & $\begin{array}{l}\text { supersaturating at temp. } \\
450{ }^{\circ} \mathrm{C} / 1,5 \mathrm{~h} \text {, cooling in air, } \\
\text { natural aging in } 3 \text { months } \\
\text { (precipitation hardening) }\end{array}$ & & & & & & & & & & & \\
\hline
\end{tabular}
The corrosion solution was the $3 \%$ solution of $\mathrm{NaCl}$, refreshed after each 7 days. The testing time was $1500 \mathrm{~h}$. The temperature

Tab. 1. Chemical constitution and heat treatment parameters used in tests of samples cut from $10 \mathrm{~mm}$ thick sheets of EN AW-AlZn5Mg1,5CuZr alloy 
of the corrosion environment ranged within $20 \div 22{ }^{\circ} \mathrm{C}$. The initial stress was set with respect to the yield point at the level of $\sigma_{0}=(0.4 \div 1.0) \mathrm{R}_{0.2}$.

\section{RESULTS OF TESTS AND THEIR ANALYSIS}

Mechanical properties of the EN AW-AlZn5Mg1,5CuZr alloy were tested in different heat treatment states (Table 1). Table 2 collects the average values of mechanical properties of the examined alloy for different heat treatments.

Tab. 2. Collection of average values of mechanical properties of the EN AW-AlZn5Mg1,5CuZr alloy for different heat treatments

\begin{tabular}{|c|c|c|c|c|}
\hline State & \multicolumn{4}{|c|}{ Mechanical properties } \\
\hline & $\begin{array}{c}\mathrm{R}_{\mathrm{m}} \\
{[\mathrm{MPa}]}\end{array}$ & $\begin{array}{c}\mathrm{R}_{0.2} \\
{[\mathrm{MPa}]}\end{array}$ & $\begin{array}{c}\mathrm{A}_{5} \\
{[\%]}\end{array}$ & $\begin{array}{c}\mathrm{Z} \\
{[\%]}\end{array}$ \\
\hline $\mathrm{T} 61$ & 479 & 442 & 9 & 22 \\
\hline $\mathrm{T} 62$ & 442 & 397 & 10 & 34 \\
\hline $\mathrm{T} 63$ & 362 & 295 & 12 & 33 \\
\hline $\mathrm{T} 4$ & 399 & 247 & 14 & 31 \\
\hline
\end{tabular}

The heat treatment parameters (T61, T62, T63), excluding the variant labelled as T4 (natural aging), significantly differ between each other only by the rate of cooling after heat treatment.

The mechanical properties of the examined alloy recorded for different heat treatment states are given in Table 2. The tests have proved that after the heat treatment denoted as T63 (cooled in air after heat treatment) the examined alloy had relatively poor mechanical properties, but remarkable plastic elongation (contraction).

In state T62 (cooled in hot water after heat treatment) the alloy had much better mechanical properties and good plastic properties, but the same alloy in state T61 (cooled in cold water after heat treatment) revealed the best mechanical properties and the worst plastic properties. In state T4 (natural aging), the alloy revealed relatively high tensile strength, but the lowest yield point.

In order to recognise possible reasons for such large differences of mechanical properties revealed by the examined alloy, the chemical constitution of which remained unchanged in all tests, the structural analysis of samples representing different heat treatments was conducted.

Metallographic specimens for microanalysis were polished and then etched using the Wasserman's reagent. Photos were taken and observations were performed in the optical microscope Neophot -2 . Moreover, the microstructures of the examined alloy were observed on thin foils in the transmission electron microscope Tesla-300. The foils were prepared on abrasive papers using a standard method, and then were electropolished in the solution having the following composition: $20 \%$ perchloric acid, $80 \%$ ethyl alcohol. The temperature of the electrolyte was approximately equal to $-40{ }^{\circ} \mathrm{C}$.

Analysing microstructures of the EN AW-AlZn $5 \mathrm{Mg} 1,5 \mathrm{CuZr}$ alloy for different heat treatment states. Figures $1 \div 3$ show the alloy microstructures for selected heat treatments.

The conducted microanalysis has made it possible to determine the PFZ width of the examined aluminium alloy for different heat treatments. The results are given in Table 3 .

Tab. 3. PFZ width of the EN AW-AlZn5Mg1,5CuZr alloy in dependence on the applied heat treatment

\begin{tabular}{|c|c|c|c|c|}
\hline Heat treatment state & T63 & T62 & T61 & T4 \\
\hline PFZ width, nm & 425.0 & 125.8 & 70.5 & 80.0 \\
\hline
\end{tabular}
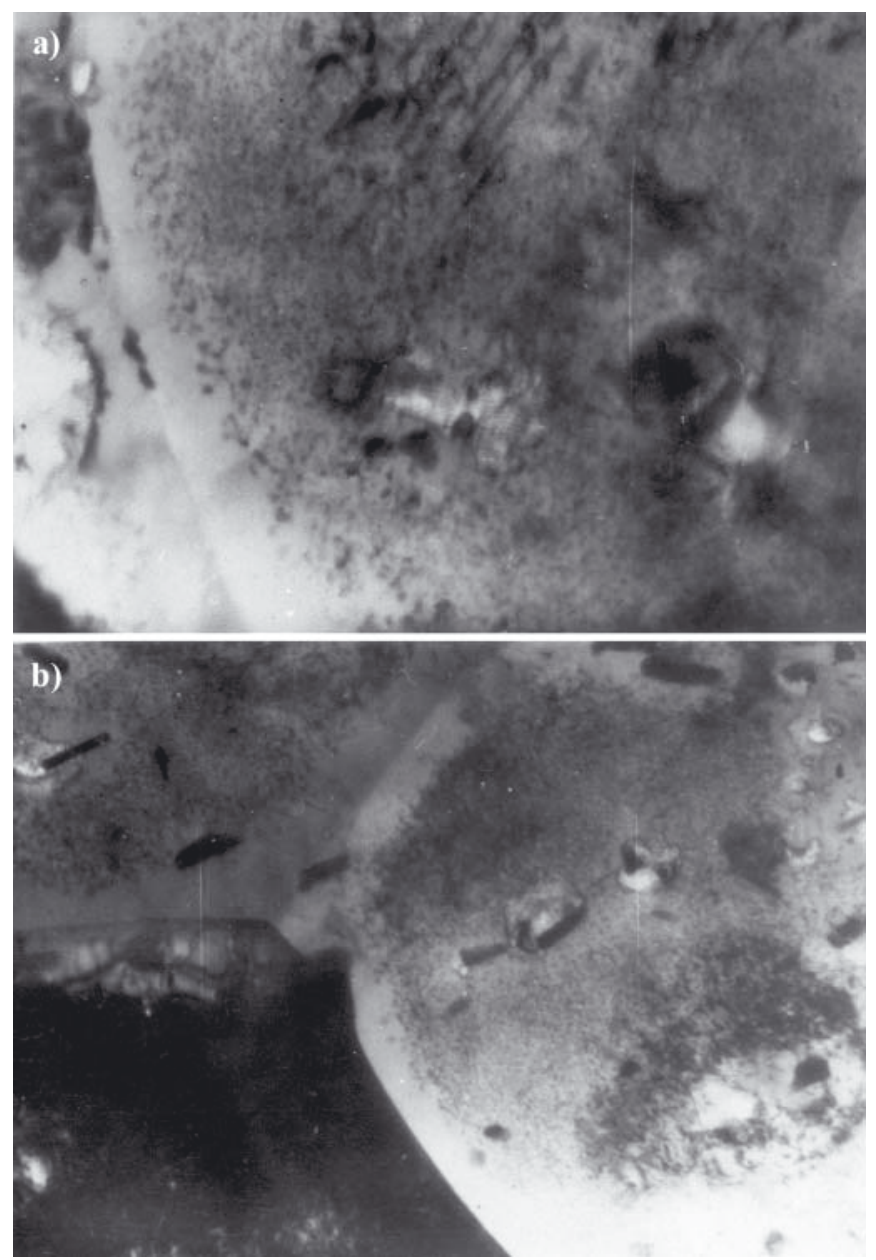

Fig. 1. Microstructure of EN AW-AlZn5Mg1,5CuZr T63 alloy, thin foil. a) magnified $32.000 x$, b) magnified $44.000 x$

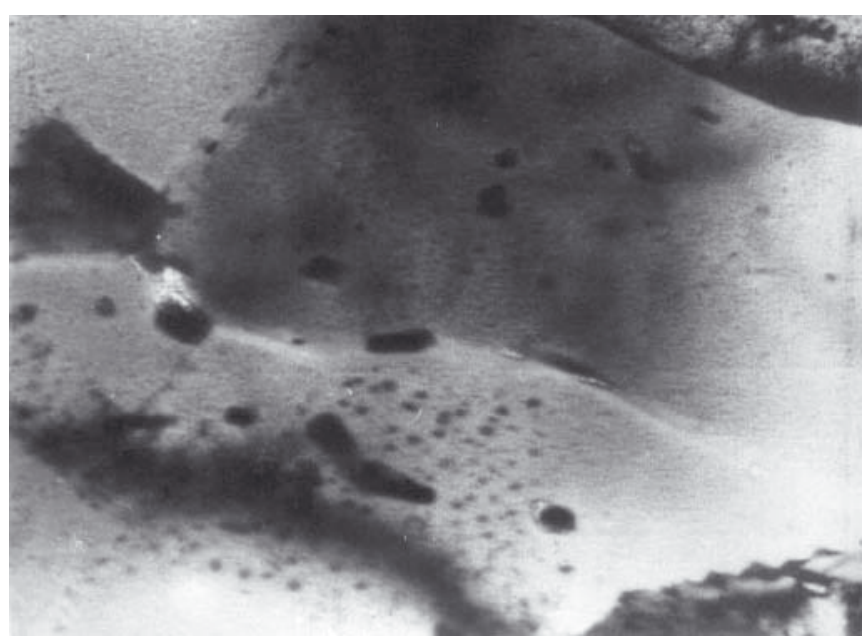

Fig. 2. Microstructure of EN AW-AlZn5Mg1,5CuZr T62 alloy, thin foil, magnified $32.000 x$

The conducted microanalysis has indicated clear correlation of the structure and mechanical properties of the examined Al$\mathrm{Zn}-\mathrm{Mg}$ alloy with the type of the performed heat treatment. The static tensile test has shown that in state T61 the alloy has better mechanical properties than in states T62 and T63. Separation of GP zones was observed in the alloy structure obtained as a result of cooling in cold water after heat treatment (T61) (Fig. 6). Their presence could be concluded from the so-called "tweed structure", being the effect of the first decomposition of solid solution. The observed precipitate free zones (PFZ) adjacent to grain boundaries had the width of $50 \div 80 \mathrm{~nm}$. 

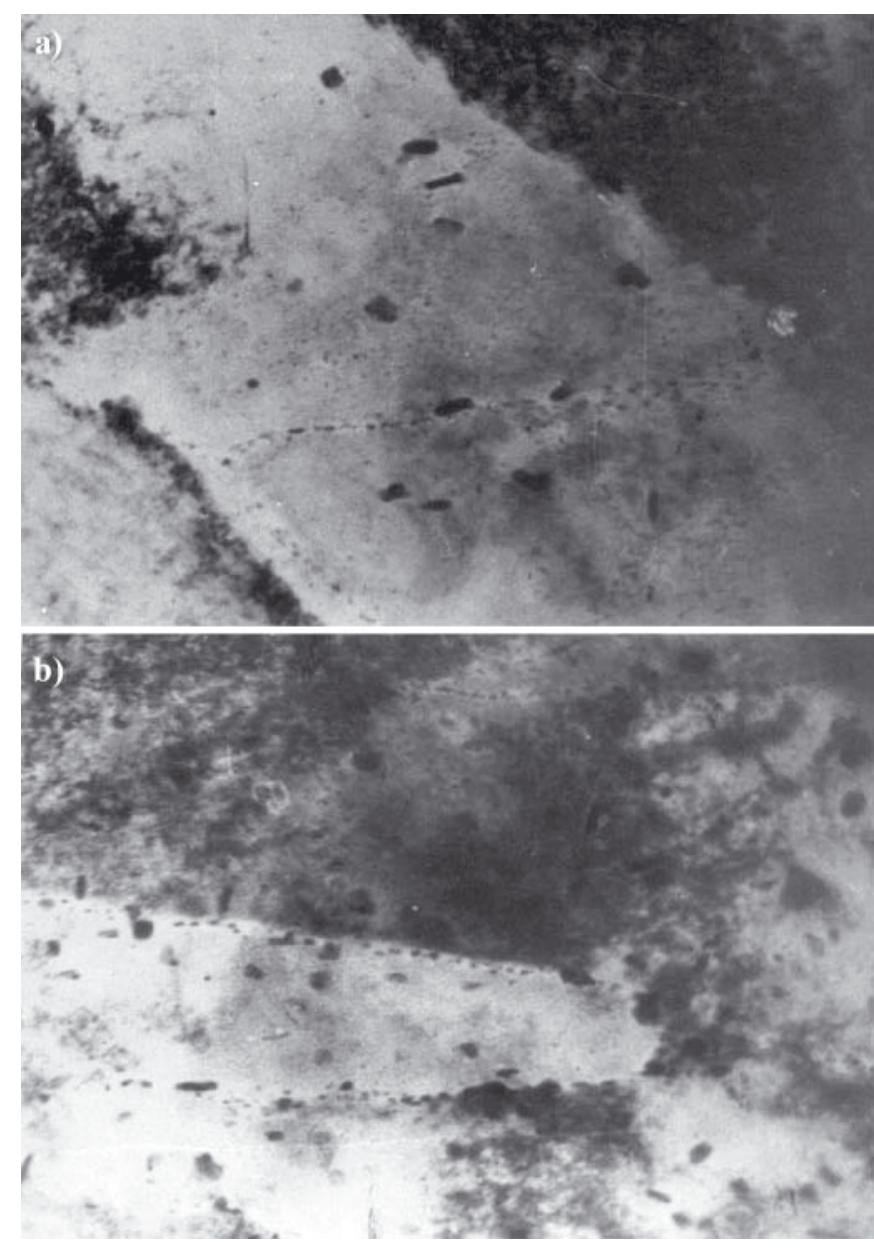

Fig. 3. Microstructure of EN AW-AlZn5Mg1,5CuZr T61 alloy, thin foil, a) magnified $32.000 x$, b) magnified $60.000 x$

Larger $\mathrm{MgZn}_{2}$ phase precipitates could be observed at grain boundaries. In the material which was air cooled after heat treatment (state T63 - Fig. 4) remarkable decomposition of the solid solution took place. Observed were fine precipitates of the transient phase $\eta^{\prime}$ and the equilibrium phase T which separated directly from the solid solution during slow cooling after heat treatment. PZF zones of $400 \div 600 \mathrm{~nm}$ in width were observed as well.

In the microstructure of the aluminium alloy in state T62 (cooling in hot water after heat treatment) shown in Fig. 5 fine precipitates of the transient phase $\eta^{\prime}$ were observed inside the grains. The $\eta$ phase $\left(\mathrm{MgZn}_{2}\right)$ precipitates which were observed at grain boundaries were arranged in rows. The PFZ width was of an order of $120 \div 200 \mathrm{~nm}$.

The microstructure of the aluminium alloy in state T4 (natural aging after heat treatment) was characteristic for the presence of continuous $\eta$ phase precipitates at grain boundaries. Inside the grains, the observed "tweed structure" testified to the presence of GP zones.

Figure 4 illustrates the effect of the PFZ width on mechanical properties of the examined aluminium alloy. The conducted microstructure analysis and static mechanical tests of the ENAW-AlZn5Mg1,5CuZr alloy have made the basis for determining the relation between the width of the precipitate free zone (PFZ) and mechanical properties. The microanalysis has showed that the PFZ width depends on the method of alloy cooling after heat treatment (more precisely: on the cooling rate). The increasing rate of cooling after heat treatment results in smaller PFZ width, which manifests itself by increased mechanical properties and decreased plasticity.

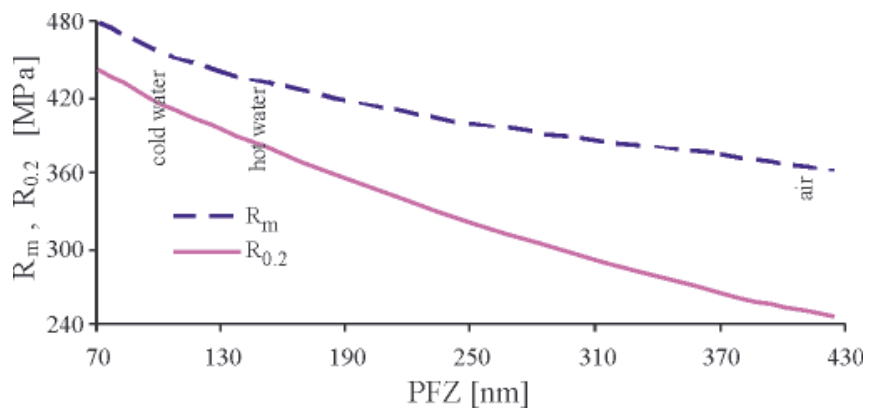

Fig. 4. PFZ width vs. mechanical properties of EN $A W-A l Z n 5 M g 1,5 C u Z r$ alloy cooling in cold water $\left(T=20^{\circ} \mathrm{C}\right)$, cooling in hot water $\left(T=80^{\circ} \mathrm{C}\right)$,

$$
\text { cooling in air }
$$

\section{Stress-corrosion resistance of EN AW- AlZn5Mg1,5CuZr alloy in different heat treatment stages}

The stress corrosion of the alloy was examined in different heat treatment states for the initial stress level $\sigma_{0} / R_{0.2}=$ $=0.60 \div 1.0$ in time $\mathrm{t}=1500 \mathrm{~h}$. After being exposed to corrosion, samples were torn on a universal testing machine MTS 810.12 in order to determine their mechanical properties.

From among 12 samples tested in state T61, 4 samples cracked in time $\mathrm{t}<1100 \mathrm{~h}$. The average durability of the material used for preparing samples did not exceed $\mathrm{t}=1000 \mathrm{~h}$ at stress level $\sigma_{0}=332 \mathrm{MPa}$, and $\mathrm{t}=2000 \mathrm{~h}$ at stress level $\sigma_{0}=$ $=100 \mathrm{MPa}$ (Fig. 5).

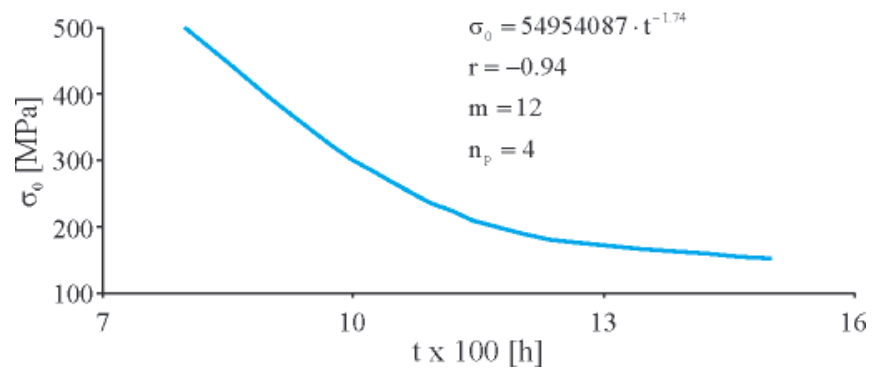

Fig. 5. Stress-corrosion durability of EN AW-AlZn5Mg1,5CuZr T61 alloy exposed to corrosion in $3 \% \mathrm{NaCl}$ solution

Figure 5 shows the curve of stress-corrosion durability of the aluminium alloy for the state T61. The accompanied changes of mechanical properties of the examined alloy after stress-corrosion exposition are given in Table 4.

Stress-corrosion tests of the alloy in state T63 have shown that none of the tested samples cracked during the testing time $\mathrm{t}=1500 \mathrm{~h}$. Symptoms of layer corrosion on samples were not observed either. The heat treatment remarkably affected the stress-corrosion resistance. The stress-corrosion tests have made the basis for determining mechanical properties of the examined samples (Table 4).

Like for state T63, also in state T62 the examined alloy did not reveal symptoms of layer corrosion. None of the tested samples was damaged in time $\mathrm{t}=1500 \mathrm{~h}$. For this state, the improvement of alloy resistance to stress corrosion was observed, as compared to state T61. Like in the previous case, the stress-corrosion tests have made the basis for determining mechanical properties of the examined samples (Table 4).

As a result of alloy tests in state T4, $50 \%$ of the tested samples cracked in time $\mathrm{t}<1100 \mathrm{~h}$. The symptoms of layer corrosion were clearly observed on the samples. Figure 10 shows the curve of stress-corrosion durability, while Table 4 collects mechanical properties of the examined samples after stress-corrosion exposition. 
Tab. 4. Percent decrease of mechanical properties of the EN AW-AlZn5Mg1,5CuZr alloy after stress-corrosion exposition, in dependence on the applied heat treatment (for stress level $\sigma_{0} / R_{02}=0.80$ )

\begin{tabular}{|c|c|c|c|c|c|}
\hline \multirow[b]{2}{*}{ Test } & \multirow[b]{2}{*}{ State } & \multicolumn{4}{|c|}{ Mechanical properties } \\
\hline & & $\begin{array}{c}\mathbf{R}_{\mathrm{m}} \\
{[\mathrm{MPa}]}\end{array}$ & $\begin{array}{c}\mathbf{R}_{0.2} \\
{[\mathrm{MPa}]}\end{array}$ & $\begin{array}{c}\mathbf{A}_{5} \\
{[\%]}\end{array}$ & $\begin{array}{c}\mathbf{Z} \\
{[\%]}\end{array}$ \\
\hline before stress corrosion & $\begin{array}{l}\text { T61 } \\
\text { T62 } \\
\text { T63 } \\
\text { T4 } \\
\end{array}$ & $\begin{array}{l}479 \\
442 \\
362 \\
399 \\
\end{array}$ & $\begin{array}{l}442 \\
397 \\
295 \\
247\end{array}$ & $\begin{array}{c}9 \\
19 \\
12 \\
14\end{array}$ & $\begin{array}{l}22 \\
34 \\
33 \\
31\end{array}$ \\
\hline after stress corrosion & $\begin{array}{l}\text { T61 } \\
\text { T62 } \\
\text { T63 } \\
\text { T4 }\end{array}$ & $\begin{array}{l}460 \\
426 \\
303 \\
150\end{array}$ & $\begin{array}{l}421 \\
377 \\
242 \\
130\end{array}$ & $\begin{array}{l}3 \\
3 \\
6 \\
1\end{array}$ & $\begin{array}{c}10 \\
9 \\
15 \\
8\end{array}$ \\
\hline & & \multicolumn{4}{|c|}{ Relative change of mechanical properties } \\
\hline & & $\begin{array}{c}\delta R_{m}=\underset{R_{m}}{\Delta} / R_{m} \\
{[\%]}\end{array}$ & $\begin{array}{c}\delta R_{0.2}=\underset{R_{0.2}}{\Delta} / \mathbf{R}_{0.2} \\
{[\%]}\end{array}$ & $\begin{array}{c}\delta \mathbf{A}_{5}=\Delta \mathbf{A}_{5} / \mathbf{A}_{5} \\
{[\%]}\end{array}$ & $\begin{array}{c}\delta Z=\Delta Z / Z \\
{[\%]} \\
\end{array}$ \\
\hline $\begin{array}{l}\text { Change of mechanical } \\
\text { properties for given } \\
\text { heat treatment state }\end{array}$ & $\begin{array}{l}\text { T61 } \\
\text { T62 } \\
\text { T63 } \\
\text { T4 }\end{array}$ & $\begin{array}{l}\downarrow 4 \\
\downarrow 4 \\
\downarrow 16 \\
\downarrow 62\end{array}$ & $\begin{array}{l}\downarrow 4 \\
\downarrow 5 \\
\downarrow 18 \\
\downarrow 48\end{array}$ & $\begin{array}{l}\downarrow 66 \\
\downarrow 70 \\
\downarrow 50 \\
\downarrow 93\end{array}$ & $\begin{array}{l}\downarrow 55 \\
\downarrow 74 \\
\downarrow 55 \\
\downarrow 74\end{array}$ \\
\hline
\end{tabular}

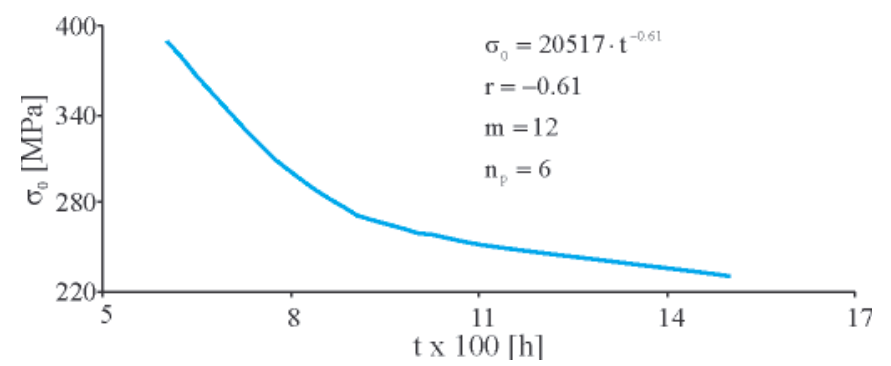

Fig. 6. Stress-corrosion durability of EN AW-AlZn5Mg1,5CuZr T4 alloy exposed to corrosion in $3 \% \mathrm{NaCl}$ solution

Analysing the obtained results of testing the effect of heat treatment of the EN AW-AlZn5Mg1,5CuZr alloy on its stresscorrosion resistance leads to the conclusion that for the state T62 (cooling in hot water after heat treatment) the alloy's resistance to stress corrosion was improved with respect to the alloy in state T61 (cooling in cold water).

Like in state $\mathrm{T} 62$, the reduced cooling rate after heat treatment (air cooling) in state T63 remarkably improved alloy's resistance to corrosion cracking. Both heat treatments T62 and T63 secured good alloy resistance to corrosion cracking. Moreover, each of given methods of artificial aging after heat treatment eliminated alloy's tendency to layer corrosion.

In the aspect of structural analyses, the resistance of the EN $\mathrm{AW}-\mathrm{AlZn} 5 \mathrm{Mg} 1,5 \mathrm{CuZr}$ alloy to corrosion cracking is explained as the effect of non-uniform concentration of inter-metallic phases (especially $\eta$ phase) and different PFZ widths.

In states $\mathrm{T} 61$ and $\mathrm{T} 4$, the $\eta$ phase precipitates at grain boundaries have continuous structure, while in states representing higher stress-corrosion resistance (T62, T63) they are not continuous any longer. Moreover, corrosion resistance of the examined aluminium alloy subjected to different cooling procedures after heat treatment increased with the increased width of the PFZ zone.

\section{CONCLUSIONS}

Mechanical properties and stress-corrosion resistance of the examined aluminium alloy EN AW-AlZn5Mg1,5CuZr depend remarkably on the applied heat treatment. Artificial aging after heat treatment makes it possible to reach higher conventional yield point $\mathrm{R}_{0,2}$, than in case of natural aging. The investigations have indicated low resistance of the alloy in state ta to stress corrosion.

In the examined artificially aged alloys (T6) mechanical properties and corrosion crack resistance depend on the cooling rate after heat treatment (aging conditions were the same for all artificially precipitation hardened states). The higher the cooling rate after heat treatment, the better the mechanical properties and the worse the stress-corrosion resistance.

The type of heat treatment affects the nature of the material structure, especially the concentration and size of inter-metallic phases, and the PFZ width. The increased rate of cooling after heat treatment, followed by artificial aging, lead to the decrease of the PFZ width. The nature of $\eta$ phase precipitates at grain boundaries also affects the corrosion resistance of the alloy. Moreover, phase precipitates revealing continuous nature worsen alloy's resistance to stress corrosion as well.

That is why the type of heat treatment (in particular the cooling rate after the heat treatment) is to be selected in such a way as to secure simultaneously high mechanical properties and good stress-corrosion resistance of the alloy at relatively low cost of the entire process. In these terms, the best results can be achieved using hot water as the cooling medium after heat treatment (state T62). The heat treatment labelled as T62 makes it possible to obtain good mechanical properties $\left(\mathrm{R}_{\mathrm{m}} \approx 440 \mathrm{MPa}, \mathrm{R}_{0.2} \approx 400 \mathrm{MPa}\right)$ and stress-corrosion durability (at $\sigma_{0}=320 \mathrm{MPa}, \mathrm{t}>1500 \mathrm{~h}$ ).

After the heat treatment T62, the examined aluminium alloy with $\mathrm{Cr}$ and $\mathrm{Zr}$ additives had the structure which secured good mechanical properties and high resistance to stress-corrosion cracks. This structure revealed uniform distribution of $\eta$ phase without continuous precipitates at grain boundaries, along with satisfactory PFZ width, approximately equal to $120 \mathrm{~nm}$.

\section{BIBLIOGRAPHY}

1. Gruhl W.: The stress corrosion behaviour of high strength AlZnMg alloys. Aluminum, 5, 1978.

2. Sinavskij V. S., Valkov V. D.: Korrozja i zaŝ̂ita aluminiovych splavov. Metallurgija, Moskva, 1986.

3. Strabawa J.: Structural analysis of stress-corrosion development in K63Cu alloy. Ph.D. thesis (in Polish), AGH, Cracow, 1974.

4. Charbonier J. C., Marandet B., Sanz G.: Methodes dessais utilisees pour la determination de $K_{I S C C}$ en milieu salin: 
application au cas de guelgues aciers a tres haute resistance. Mateaux, 50, No 599-600, 1975.

5. Cudny K., Puchaczewski N.: Metal alloys for ship hulls (in Polish). Wydawnictwo Morskie, Gdańsk 1989.

6. Bugłacki H.: The effect of heat treatment and chemical constitution on mechanical properties and stress corrosion of the AlZn5Mg1 alloy in welded ship constructions. Ph. D. thesis (in Polish). Gdansk University of Technology. Gdańsk, 1981.

7. Cudny K et. al.: Summary of examination of weldability and corrosion resistance of the AlZn $5 \mathrm{Mg} 3$ alloy. Scientific research report (in Polish). WSMW, Gdynia 1984.

8. Cudny K., Wójcik J.: Testing the tendency to hot crack of the AlZn5Mg1 alloy welded with AlMg5 and AlMg5Zn2 binders with different zirconium content (in Polish). Zeszyty Naukowe WSMW, Gdynia Nr 1/60, 1979.

9. Report on scientific research "Light alloys", stage II, (in Polish). WSMW Gdynia, 1982.

10. Yoshimitsu M.: Influence of applied stress and test temperature on stress corrosion cracking of Al-Zn-Mg alloy. Journal Japan Institute Light Metals, No 12, 1976.
11. Brown B F.: A new stress-corrosion cracking test for high strength alloys. Material Research and Standards, No 3, 1966.

12.Kowarsch A., Bugłacki H.: Testing the effect of stress corrosion on strength of precipitation hardened Al-Zn-Mg alloys (in Polish). Ochrona przed korozja, Nr 1, 1979.

13.Kyzioł L., Czapczyk K.: Influence of heat treatment on stress -corrosion resistance of EN AW-AIZn $5 \mathrm{Mg} 1,5 \mathrm{CuZr}$ alloy, Solid State Phenomena, Mechatronic System and Materials Vol. 199, 2013, pp. 424-429.

\section{CONTACT WITH THE AUTHOR}

Lesław Kyzioł, Assoc. Prof. Faculty of Marine Engineering, Gdynia Maritime University Morska 81/87 81-225 Gdynia, POLAND e-mail: 1kyz@am.gdynia.pl 